\title{
ODONTOMETRIC INDICES FLUCTUATION IN PEOPLE WITH PHYSIOLOGICAL OCCLUSION
}

\section{Vladimir Shkarin', Dmitry Domenyuk ${ }^{2}$ Alexander Lepilin ${ }^{3}$, Igor Fomin ${ }^{4}$, Sergei Dmitrienko ${ }^{5}$} 'Department of public health and health care of doctor's improvement
faculty, Volgograd State Medical University, Volgograd, Russia

2 Department of general practice dentistry and child dentistry, Stavropol state medical university of Ministry of healthcare, Stavropol, Russia

${ }^{3}$ Department of Surgical Dentistry and Maxillofacial Surgery, Saratov State Medical University, Saratov, Russia

${ }^{4}$ Department of Orthopedic and General Dentistry, Sechenov First Moscow State Medical University, Moscow, Russia

${ }^{5}$ Department of Dentistry, Pyatigorsk Medical-Pharmaceutical Institute, Pyatigorsk, Russia

\section{Correspondence address:}

Department of general practice dentistry and child dentistry,

Stavropol state medical university of Ministry of healthcare,

310, Mira Street, Stavropol, Russia 355017.

E-mail:domenyukda@mail.ru, tel: +7(918)870-1205.

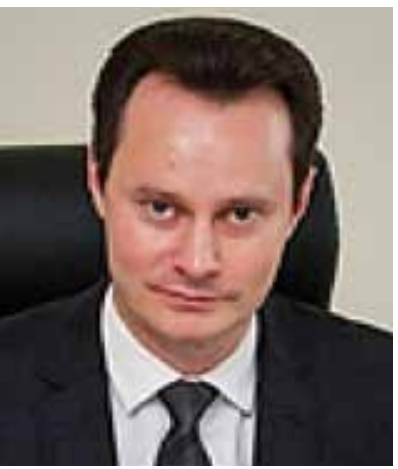

Vladimir Shkarin, Candidate of Medical Science, Associate Professor, Head of Department

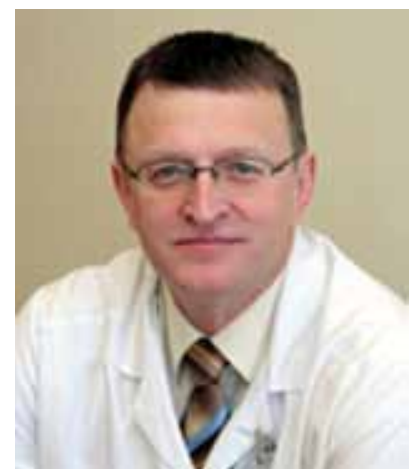

Alexander Lepilin,

Prof. $M D, P h D$

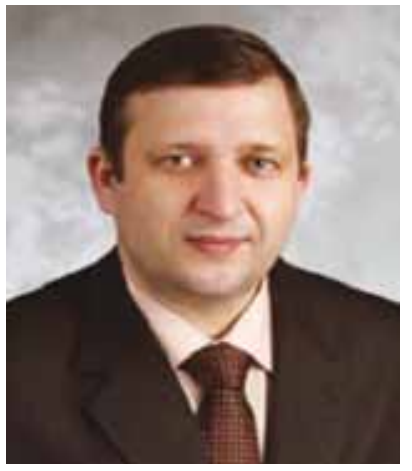

Dmitry Domenyuk, Doctor of Medicine, Professor

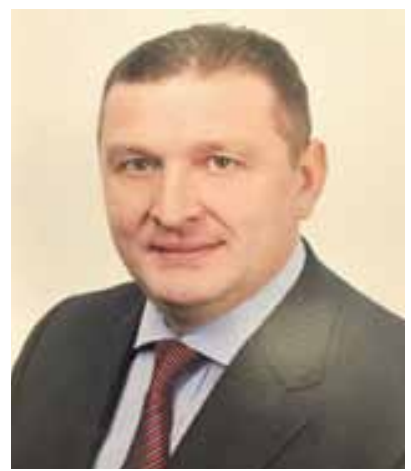

Igor Fomin, $D r$., $M D$, Associate Professor

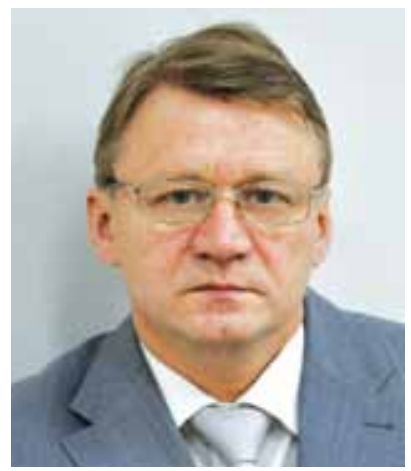

Sergey Dmitrienko Doctor of Medicine, Professor, Head of Department studies variations in the human teeth anatomy, allows not only identifying certain regularities in the shape and size of teeth, depending on the gender, ethnicity and race, yet also developing some theoretical basics promoting further this branch of anthropology, as well as defining concepts and formulations that are of applied value in dentistry $[1,21,22,28,31,35]$.

ABSTRACT - Biometric examinations of jaw stone models and tomography images of 310 people (both genders) in their first adulthood stage with permanent teeth physiological occlusion were used to study the morphometric parameters of dental types and dental arches gnathic types in each patient. Odontometric procedure included evaluation of the crowns mesial-distal width involving the calculation of the arithmetic mean, the maximum and the minimum values, in order to estimate the deviations from the mean value (fluctuation). The outcomes suggest that there was no statistically significant difference between the odontometric parameters obtained from men and women. The significant variability in the frontal teeth size in women, compared with men, indicates that the size is only slightly dependent on gender, while is determined by the dental system type. In measurements done without taking into account the dental type, it can be hard to determine sexual dimorphism due to the fluctuating nature of the odontometric indices.

KEYW ORDS — craniometry, sexual dimorphism, dental type, odontometry, normodontia.

The advances in Dental Anthropology (Anthropological Odontology), a science that 
At present, the fluctuation of the gender-related features of the dentoalveolar system has a biological meaning, which is the reflection of the gene pool. Some odontological features are known to have stable gender differences in view of the racial specifics $[3,32,39]$.

The indicator of sexual dimorphism is the ratio of the difference in the male and female features to the feature that occurs in males $[2,5,7,11,25,37]$.

The tooth size sexual dimorphism, according to $\mathrm{K}$. Hanihara (1967), is subject to fluctuations, the causes of which have not been studied well enough yet.

According to A.J. Perzigian (1984), the size of the teeth correlates with growth, and taller people have been observed to have teeth of larger size than shorter ones. In this connection, manifestations of sexual dimorphism may take place [38].

Nevertheless, most experts agree that sexual dimorphism is of fluctuating nature if viewed based on a feature like the size of the teeth. In this regard, it is recommended that sampling be done observing proportional correlation by the age, as well as sexual and racial features [36].

It is worth noting the opinion of some experts pointing at the dependence of the teeth size on the gnathic and dental types of dental arches $[14,17,19,23]$. Besides, there was an indication of correlational dependence that the dental arch dimensions have on the craniofacial parameters and, in particular, on the dimensions of the gnathic part of the face $[9,27,29]$.

The taxonomic value of odontological features is due to the rigid genetic determination, their functional independence from each other as well as from other feature systems, the absence of age-related variability and directional inter-gender differences, phylogenetic age, stability, and clear geographic proximity. Taxonomic disparity of odontological features suggests more detailed distribution of the groups taking into account the current status of the entire issue in question. Recently, for instance, classifications of dental arches have been proposed in view of the gnathic and dental parameters $[6,8,12,15,33]$. Nine basic types of dental arches are distinguished with physiological occlusion, which take into account the gnathology (meso-, brachy- and dolichognathy) and odontometry (macro-, micro- and normodontia) $[4,10,13,16,18,20,24,26,30,34,40]$.

Despite the numerous odontometric studies on sexual dimorphism, we have not encountered works offering a comparative study of males-female teeth size in view of the dental arches type, namely, in cases of normodontia.

To determine the odontometric fluctuations in people with physiological occlusion in terms of sexual dimorphism with normodontia of permanent teeth.

\section{MATERIALS AND METHODS}

A biometric study was carried out involving 310 people (both females and males; age - 21-35, the first stage of adulthood) with physiological occlusion of permanent teeth. The odontometric and the linear parameters were measured on stone models of jaws, as well as through analyzing the data obtained with cone-beam computed tomography (Fig. 1).

Through the study, the participants were distributed based on their gender, taking into account their dental system type, which was identified based on the length of the. In cases of normodontia, the sum total of the mesial-distal crowns width for the 14 teeth constituting the upper jaw dentition varied from $110 \mathrm{~mm}$ to $118 \mathrm{~mm}$. The gnathic type of the dental arch was identified through a computer tomogram, as the dental arch depth ratio to the width between the second molars. In cases with mesognathia the ratio was $0.74 \pm 0.03$.

The average module of molars was determined based on the half-sum of the first and second molars modules. To be noted that the value of the module was taken as the half-sum of the mesial-distal and vestibularlingual molar crown size.

In the anterior teeth and premolars odontometry, only the mesial-distal width of the crowns was taken into account. Calculation was performed for the arithmetic mean, maximum and minimum values of the odontometric index. The feature fluctuation was estimated focusing on the deviation from the mean value (feature fluctuation).

The statistical processing was performed directly from the common data matrix of ECXEL 7.0 (Microsoft, USA) also involving certain features offered by the STATGRAPH 5.1 (Microsoft, USA) software, ARCADA (Dialog-MGU, Russia), and implied detecting the median values, its mean root square deviation, and the non-sampling error. Further on, following the patterns commonly employed for medical and biological studies (sample numbers; type of distribution; non-parametric criteria; reliability of the difference of $95 \%$, etc.) the significance of the sampling difference was evaluated subject to the Student's criterion $(t)$ and the respective significance index (p).

\section{RESULTS AND DISCUSSION}

The results show that the overall pattern of the odontometric parameters variations is of a fluctuating nature. The fluctuation from the mean value has revealed a fairly significant range (Table 1 ).

The difference between the maximum and minimum values of the mesial-distal width of the upper medial incisor crown in case of physiological occlusion is about $2 \mathrm{~mm}$.

The difference in the length of the dental arch 

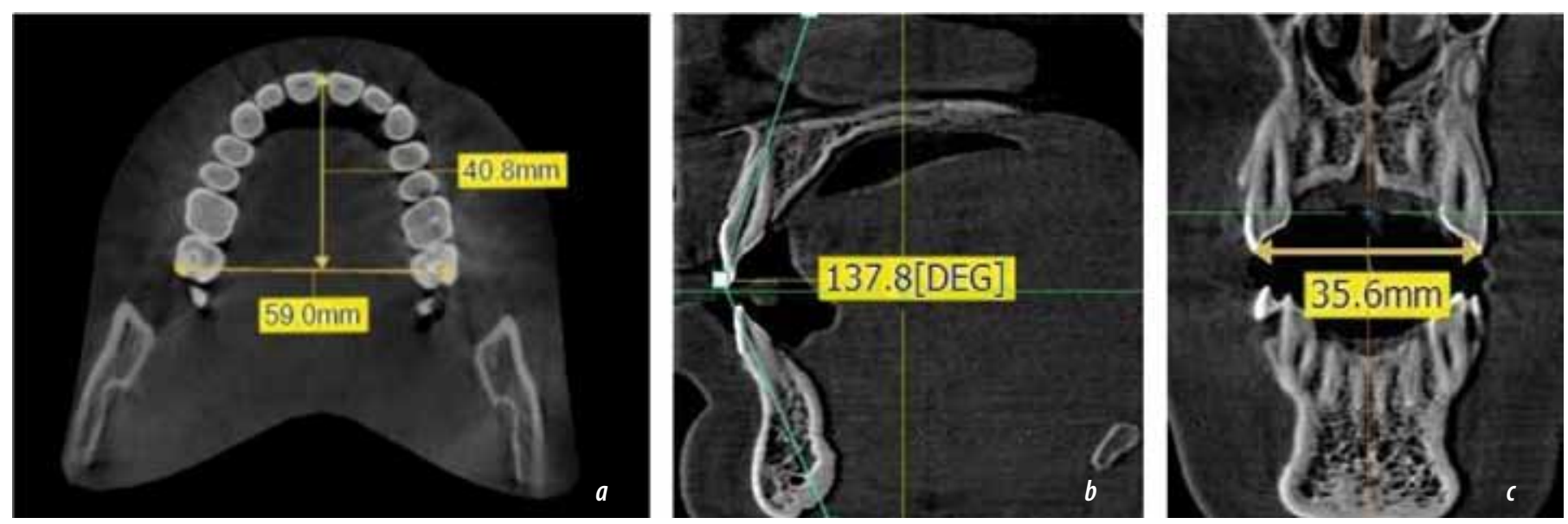

Fig. 1. Specific features of measuring linear and angular parameters on a computer tomogram, horizontal (a), sagittal (b) and vertical (c) planes

Table 1. Major odontometric indices in people with physiological occlusion of the upper and lower permanent teeth, $(m m),(M \pm m),(p \leq 0,05)$

\begin{tabular}{|c|c|c|c|c|c|c|}
\hline \multirow{3}{*}{$\begin{array}{l}\text { Odontometric } \\
\text { parameters }\end{array}$} & \multicolumn{6}{|l|}{ Size } \\
\hline & \multicolumn{3}{|l|}{ Upper jaw } & \multicolumn{3}{|l|}{ Lowe jaw } \\
\hline & average & $\max$ & $\min$ & average & $\max$ & $\min$ \\
\hline Medial incisor & $9,10 \pm 0,18$ & $10,09 \pm 0,27$ & $8,11 \pm 0,09$ & $5,45 \pm 0,12$ & $6,01 \pm 0,19$ & $4,69 \pm 0,05$ \\
\hline Lateral incisor & $6,52 \pm 0,14$ & $7,71 \pm 0,22$ & $5,32 \pm 0,07$ & $5,97 \pm 0,14$ & $6,68 \pm 0,17$ & $5,27 \pm 0,12$ \\
\hline Canine & $7,94 \pm 0,23$ & $8,69 \pm 0,29$ & $7,19 \pm 0,18$ & $6,79 \pm 0,23$ & $7,73 \pm 0,26$ & $5,86 \pm 0,21$ \\
\hline $\begin{array}{l}\text { Sum of the six } \\
\text { anterior teeth }\end{array}$ & $46,76 \pm 1,26$ & $51,78 \pm 1,48$ & $41,74 \pm 1,03$ & $35,94 \pm 1,12$ & $40,22 \pm 1,36$ & $31,66 \pm 0,87$ \\
\hline $\begin{array}{l}\text { Sum of } \\
\text { the } 14 \text { teeth }\end{array}$ & $109,62 \pm 2,66$ & $112,82 \pm 3,24$ & $106,42 \pm 2,08$ & $109,03 \pm 2,87$ & $118,18 \pm 3,61$ & $99,88 \pm 2,14$ \\
\hline $\begin{array}{l}\text { Molar average } \\
\text { module }\end{array}$ & $10,95 \pm 0,37$ & $11,85 \pm 0,41$ & $10,04 \pm 0,34$ & $10,78 \pm 0,35$ & $11,62 \pm 0,43$ & $9,93 \pm 0,28$ \\
\hline
\end{tabular}

anterior section, which is defined as the width sum for the six anterior teeth crowns, can reach a maximum of $10 \mathrm{~mm}$ between the maximum and minimum values.

The lower jaw presents the same picture, yet the digital indices range is smaller.

The obtained results are consistent with the opinion expressed by most experts dealing with odontometric issues.

At the same time, we carried out a study taking into account the dental system type. 178 participants were identified as having the normodontia type of the dental system, which was $57.42 \pm 2.81 \%$ of the entire number of the participants with physiological occlusion. Besides, 82 of them were males $(26.45 \pm 2.5 \%)$ and 96 females $(30.97 \pm 2.62 \%)$. Almost twice as many people were found to have signs of macrodontia $(79-25.48$ $\pm 2.47 \%)$. The number of men and women was nearly same $-42(13.55 \pm 1.94 \%)$ and 38 persons $(11.93 \pm$ $1.84 \%)$ respectively. The lowest was the number of participants with microdontia dental systems ( 53 in the group; $17.1 \pm 2.14 \%)$. Microdontia was significantly more typical of women (38 persons, i.e. $12.26 \pm 1.86 \%$ ). As for men, only 15 of them $(4.84 \pm 1.22 \%)$ had signs of microdontia (Fig. 2).

Of the total number of the participants, we examined a group of persons distributed based on their gender, who had normodontia of permanent teeth.

Those with normodontia dental systems, the rate of the difference in the numerical values obtained from men and women to that obtained from males, varied from $1.5 \%$ to $3 \%$, which is less determinant regarding sexual dimorphism features. The major dimensions of the teeth depend on the gnathic and dental type.

Table 2 below offers a view on the results of the upper jaw teeth parameters in people of different gender.

The difference between the maximum and minimum values of the mesial-distal width of the upper medial incisor crown in case of physiological occlusion in people with normodontia does not exceed $1 \mathrm{~mm}$, which is significantly lower than a similar value obtained 

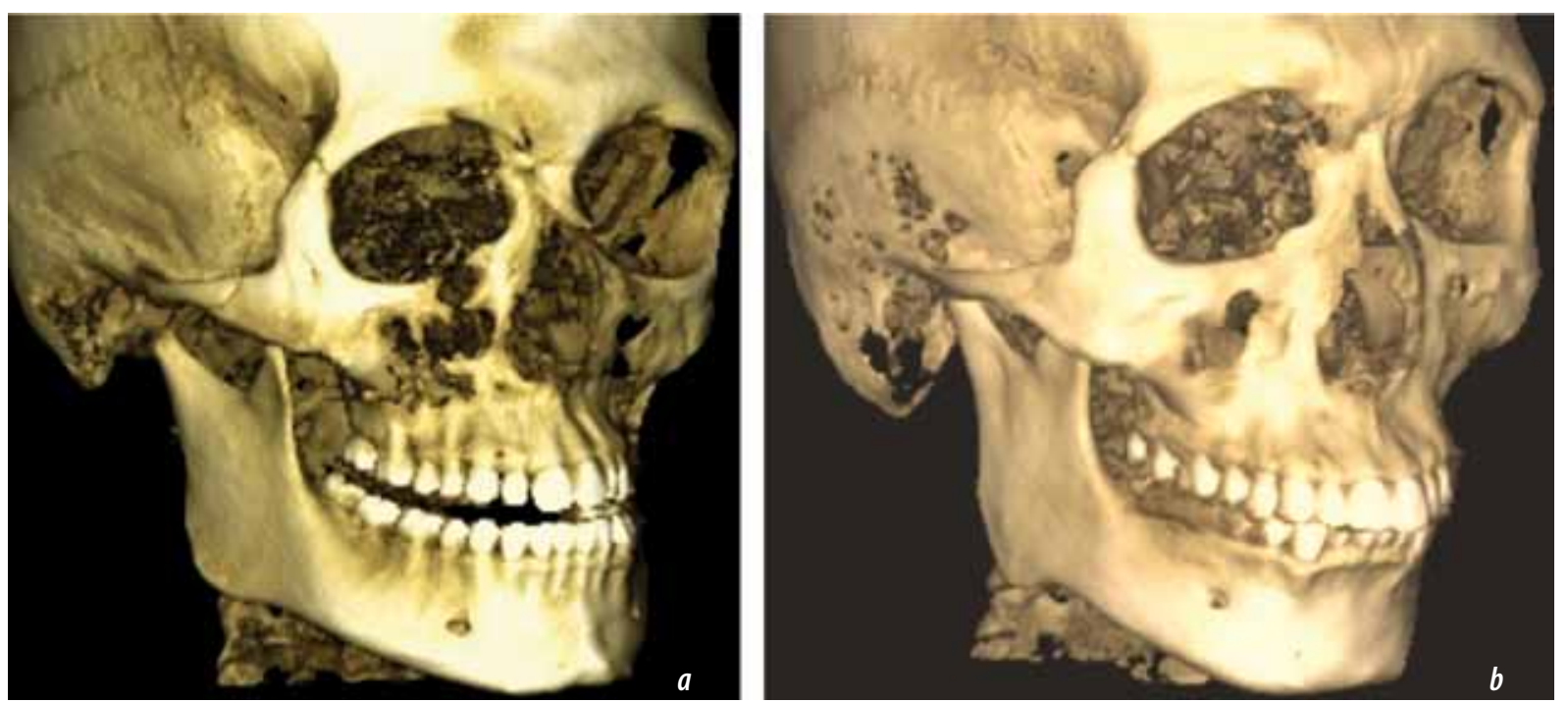

Fig. 2. Specific craniofacial features (CT imaging) with permanent teeth microdontia (a) and macrodontia (b).

Table 2. The major indicators of the upper jaw permanent teeth in people (males and females) with physiological occlusion and normodontia, (mm), $(M \pm m),(p \leq 0,05)$

\begin{tabular}{l|l|l|l|l|l|l}
\hline \multirow{2}{*}{$\begin{array}{l}\text { Odontometric } \\
\text { parameters }\end{array}$} & \multicolumn{5}{l}{ Teeth size } & \multicolumn{5}{l}{ Females } & \multicolumn{2}{l}{} \\
\cline { 2 - 7 } & aves & $\max$ & $\min$ & average & $\max$ & $\min$ \\
\hline Medial incisor & $8,78 \pm 0,27$ & $9,28 \pm 0,36$ & $8,29 \pm 0,19$ & $8,45 \pm 0,22$ & $8,79 \pm 0,29$ & $8,11 \pm 0,16$ \\
\hline Lateral incisor & $6,87 \pm 0,14$ & $7,36 \pm 0,21$ & $6,39 \pm 0,08$ & $6,45 \pm 0,16$ & $7,27 \pm 0,23$ & $5,63 \pm 0,09$ \\
\hline Canine & $7,91 \pm 0,19$ & $8,33 \pm 0,24$ & $7,49 \pm 0,15$ & $7,76 \pm 0,19$ & $8,21 \pm 0,28$ & $7,32 \pm 0,11$ \\
\hline $\begin{array}{l}\text { Sum of the six } \\
\text { anterior teeth }\end{array}$ & $47,20 \pm 1,36$ & $48,38 \pm 1,49$ & $46,02 \pm 1,24$ & $45,69 \pm 1,31$ & $48,54 \pm 1,54$ & $42,84 \pm 1,08$ \\
\hline $\begin{array}{l}\text { Sum of } \\
\text { the 14 teeth }\end{array}$ & $114,15 \pm 3,35$ & $115,86 \pm 3,47$ & $112,44 \pm 3,23$ & $113,33 \pm 3,21$ & $115,98 \pm 3,32$ & $110,68 \pm 3,09$ \\
\hline $\begin{array}{l}\text { Molar average } \\
\text { module }\end{array}$ & $10,58 \pm 0,33$ & $10,75 \pm 0,37$ & $10,41 \pm 0,28$ & $10,96 \pm 0,34$ & $11,81 \pm 0,41$ & $10,11 \pm 0,26$ \\
\hline
\end{tabular}

from a study of patients without taking into account the dental arches type.

Notable is the significant reduction in the difference between the maximum and minimum values of the anterior part of the dental arch length, which is defined as the sum of the width of the six anterior teeth crowns, which does not exceed $2.5 \mathrm{~mm}$.

There was no significant difference between the indicators obtained from males and females. The variability in the sizes of the six anterior teeth in females was above that in males. These values indicate that the teeth size depends on gender to a smaller extent if compared to the type of the dental system.

Table 3 contains the results of the study concerning the mandibular teeth parameters (males and females).
The lower jaw reveals a situation similar to that of the upper dental arch, while the digital indices range is smaller. There was no significant difference observed between the indicators obtained from males and females.

\section{CONCLUSIONS}

1. When performing odontometric studies, the evaluation and the interpretation of the results should be done in view of the dental system type.

2. The dental system type should be evaluated along the dental arch length, namely, the sum of the mesial-distal width of the crowns of the 14 permanent teeth that make up the dentition.

3. When performing odontometric studies without taking into account the dental system type, the features deviate significantly from the average value, which 
Table 3. The major indicators for the lower jaw in permanent teeth in people with physiological occlusion and normodontia, $(\mathrm{mm}),(M \pm m),(p \leq 0,05)$

\begin{tabular}{|c|c|c|c|c|c|c|}
\hline \multirow{3}{*}{$\begin{array}{l}\text { Odontometric } \\
\text { parameters }\end{array}$} & \multicolumn{6}{|l|}{ Teeth size } \\
\hline & \multicolumn{3}{|l|}{ Males } & \multicolumn{3}{|l|}{ Females } \\
\hline & average & $\max$ & $\min$ & average & $\max$ & $\min$ \\
\hline Medial incisor & $5,61 \pm 0,17$ & $5,99 \pm 0,21$ & $5,23 \pm 0,14$ & $5,37 \pm 0,16$ & $5,75 \pm 0,23$ & $4,99 \pm 0,09$ \\
\hline Lateral incisor & $6,07 \pm 0,16$ & $6,56 \pm 0,19$ & $5,57 \pm 0,12$ & $6,04 \pm 0,19$ & $6,45 \pm 0,26$ & $5,63 \pm 0,13$ \\
\hline Canine & $7,17 \pm 0,24$ & $7,64 \pm 0,28$ & $6,69 \pm 0,21$ & $6,66 \pm 0,14$ & $7,01 \pm 0,22$ & $6,31 \pm 0,07$ \\
\hline $\begin{array}{l}\text { Sum of the six } \\
\text { anterior teeth }\end{array}$ & $36,97 \pm 1,12$ & $38,62 \pm 1,27$ & $35,32 \pm 0,96$ & $35,77 \pm 1,04$ & $37,58 \pm 1,19$ & $33,96 \pm 0,88$ \\
\hline $\begin{array}{l}\text { Sum of } \\
\text { the } 14 \text { teeth }\end{array}$ & $108,48 \pm 2,97$ & $112,08 \pm 3,16$ & $104,88 \pm 2,78$ & $105,09 \pm 2,94$ & $108,96 \pm 3,08$ & $101,23 \pm 2,81$ \\
\hline $\begin{array}{l}\text { Molar average } \\
\text { module }\end{array}$ & $10,76 \pm 0,27$ & $10,95 \pm 0,31$ & $10,56 \pm 0,24$ & $10,37 \pm 0,26$ & $10,78 \pm 0,34$ & $9,96 \pm 0,19$ \\
\hline
\end{tabular}

makes it difficult to determine sexual dimorphism and is of fluctuating nature.

4. The outcomes of odontometric parameters examination concerning sexual dimorphism are of applied value in terms of restorative dentistry, where the focus is on restoring and replacing teeth, as well as in forensic practice implying identification of people subject to their dental status.

\section{REFERENCES}

1. DAVydov B.N., Vedeshina E.G., DMitrienko S.V., DomenYuk D.A. Radiological and morphometric methods for comprehensive assessment of cephalo-odontologic status in dental patients (Part I). The Dental Institute. 2017; 75(2):58-61. (In Russ.).

2. Davydov B.N., Vedeshina E.G., DMitrienko S.V., DomenYuk D.A. Radiological and morphometric methods for comprehensive assessment of cephalo-odontologic status in dental patients (Part II). The Dental Institute. 2017; 76(3): 32-35. (In Russ.).

3. DAVYdov B.N., DoMENYUK D.A., VEDESHINA E.G., DMitrienko S.V. Biometric justification of main linear dimensions of the dental arches in orthodontic treatment tactics' development using edgewise orthodontic technique (Part I). The Dental Institute. 2016;1(70):76-78. (In Russ.).

4. Davydov B.N., Domenyuk D.A., Vedeshina E.G., DMitrienko S.V. Biometric justification of main linear dimensions of the dental arches in orthodontic treatment tactics' development using edgewise orthodontic technique (Part II). The Dental Institute. 2016;2(71):66-67.

5. Davydov B.N., Domenyuk D.A., Porfyriadis M.P., Vedeshina E.G., DMitrienko S.V. Features of tactics and principles orthodontic treatment of patients with dental arches asymmetry caused by different amounts of antimeres (Part I). The Dental Institute. 2017;4(77):64-68.

6. DMitrienko S.V., Domenyuk D.A., KoChKonyan A.S., Karslieva A.G., DMitrienko D.S. Interrelation between sagittal and transversal sizes in form variations of maxillary dental arches / / Archiv EuroMedica, 2014. - Vol. 4. - No 2. - P. 10-13.

7. Dmitrienko S.V., Domenyuk D.A., Vedeshina E.G. Shape individualization in lower dental arches drawn on basic morphometric features // Archiv EuroMedica, 2015. - Vol. 5. - № 1. - P. 11-15.

8. Domenyuk D.A., Vedeshina E.G., DMitrienko S.V. Anatomic and topographic rationale for dental arch constructing and measuring methods. Kubanskij nauchnyj medicinskij vestnik. 2015;(3):31-37. (In Russ.) DOI:10.25207/1608-6228-2015-3-31-37.

9. Domenyuk D.A., Shkarin V.V., Porfiriadis M.P., DMitrienko D.S., DMitrienko S.V. Classification of facial types in view of gnathology // Archiv EuroMedica, 2017. - T.7. - No 1. - C. 8-13.

10. Domenyuk D.A., Vedeshina E.G., Dmitrienko S.V., Orfanova Z.S. Comparative analysis of dentoalveolar arch morphometric parameters in case of arch shape variations. Kubanskij nauchnyj medicinskij vestnik. 2015;(2):63-69. (In Russ.) DOI:10.25207/1608-6228-2015-2-63-69.

11. Domenyuk D.A., Vedeshina E.G., Dmitrienko S.V. Correlation of dental arch major linear parameters and odontometric indices given physiological occlusion of permanent teeth in various face types // Archiv EuroMedica, 2016. - Vol. 6. - No 2. - P. 18-22.

12. Domenyuk D.A., Vedeshina E.G., Dmitrienko S.V. Dynamics of changes in transverse and frontalretromolar jaw sizes in children throughout the orthodontic treatment stages. Kubanskij nauchnyj medicinskij vestnik. 2016;(3):51-59. (In Russ.) DOI:10.25207/1608-6228-2016-3-51-59.

13. Domenyuk D.A., Vedeshina E.G., Dmitrienko S.V. Efficiency evaluation for comprehensive treatment of patients with dental arches asymmetry at similar number of antimeres. Kubanskij nauchnyj medicinskij vestnik. 2016;(6):42-54. (In Russ.) DOI:10.25207/1608-6228-2016-6-42-54.

14. Domenyuk D.A., Vedeshina E.G., Dmitrienko S.V. Efficiency evaluation for integrated approach to choice of orthodontic and prosthetic treatments in 
patients with reduced gnathic region // Archiv EuroMedica. - 2015. - Vol. 5. - No 2. - P. 6-12.

15. Domenyuk D.A., Shkarin V.V., Porfyriadis M.P., DMitrienKo D.S., DMITRIENKO S.V. Algorithm for forecasting the shape and size of dental arches front part in case of their deformations and anomalies // Archiv EuroMedica, 2017. - T. 7. - No 2. - C. 105-110.

16. Domenyuk D.A., Tashueva L.V., Zelensky V.A., IVANCHEVA E.N. Evaluation of microvasculature tissues viability after the imposition of removable orthodontic appliances in children and adolescents // Archiv EuroMedica, 2013. - Vol. 3. - No 1. - P. C. 5-9.

17. Domenyuk D.A., Vedeshina E.G., Dmitrienko S.V. Mistakes in Pont (Linder-Harth) method used for diagnosing abnormal dental arches in transversal plane // Archiv EuroMedica, 2016. - Vol. 6. - No 2. - P. 23-26.

18. Domenyuk, D.A. Modern classification of dental arches / D.A. Domenyuk, S.V. Dmitrienko // Archiv EuroMedica, 2014. - Vol. 4. - No 2. - P. 14-16.

19. Domenyuk D.A., Vedeshina E.G. Morphometric parameters of brachygnathic dental arches considering size of permanent teeth. Kubanskij nauchnyj medicinskij vestnik. 2015;(6):47-53. (In Russ.) DOI:10.25207/1608-6228-2015-6-47-53.

20. Domenyuk D.A., Vedeshina E.G., DMitrienko S.V. Special features of dolichognathic dental arches in people with teeth size variations. Kubanskij nauchnyj medicinskij vestnik. 2016;(1):39-46. (In Russ.) DOI:10.25207/1608-6228-2016-1-39-46.

21. Domenyuk D.A., Vedeshina E.G., Dmitrienko S.V. Teeth sizes in their correlation with parameters of dentofacial arches and maxillofacial area based on native cranial preparations examination. Kubanskij nauchnyj medicinskij vestnik. 2016;(2):71-79. (In Russ.) DOI:10.25207/1608-6228-2016-2-71-79.

22. Domenyuk D.A., Vedeshina E.G., DMitrienko S.V. The use of craniometric and morphological studies in the assessment of structural elements of the temporomandibular joint. Kubanskij nauchnyj medicinskij vestnik. 2017;1(1):33-40. (In Russ.) DOI:10.25207/1608-6228-2017-1-33-40.

23. Domenyuk, D.A. Study of the spectrum of dental composites biological activity in model experiments in vitro / D.A. Domenyuk, E.G. Vedeshina, V.A. Zelensky, K.G. Karakov, M.P. Porfiriadis, I.A. Bazikov, F. N. Gilmiyarova // Medical news of North Caucasus. 2016. - Vol. 11. - No 2. - P. 179-183. (In Russ.) DOI: 10.14300/mnnc.2016.11031

24. Domenyuk, D.A. Semiquantitative evaluation of caries microflora in patients with dental and alveolar abnormalities and different severity of morphofunctional disturbances / D.A. Domenyuk, E.G. Vedeshina, V.A. Zelensky, K.G. Karakov, M.P. Porfiriadis // Medical news of North Caucasus. 2015. - Vol. 10. - No 3. - P. 238-241. (In Russ.) DOI: 10.14300/ mnnc.2015.10055.
25. Domenyuk D.A., IliJev D.M., BudayChiev G.MA., Vedeshina E.G., Dmitrienko S.V. Optimization of diagnostics and planning of orthodontic treatment of patients with dentofacial anomalies based on the results of morphometric studies of the anterior dental arch. Kubanskij nauchnyj medicinskij vestnik. 2017; 25(5): 14-21. (In Russ., English abstract). DOI: 10.25207 / 1608-6228-2017-24-5-14-21.

26. Domenyuk D.A., DMitrienko S.V., Vedeshina E.G., Risovanny S.I., Porfyriadis M.P., BudayCHIEV G.M-A. Methods of biometrical diagnostics in transversal direction in patients with mesognathic type of dental arches. Kubanskij nauchnyj medicinskij vestnik. 2017; 24(6): 26-34. (In Russ., English abstract). DOI: 10.25207 / 1608-6228-2017-24-6-26-34.

27. Domenyuk D.A., Dmitrienko S.V., Vedeshina E.G., Porfyriadis M.P., Budaychiev G.M-A. Analytical approach in evaluating the relations of odontometric indicators and linear parameters of dental arcs in people with various face types. Kubanskij nauchnyj medicinskij vestnik. 2018; 25(1): 73-81. (In Russ., English abstract). DOI: 10.25207 / 1608-62282018-25-1-73-81.

28. Domenyuk D.A., Porfyriadis M.P., Ilijev D.M., Budaychiev G.M-A., Vedeshina E.G., DMitrienko S.V. Dimensional and topographic features of the elements of the temporomandibular joint with mesial occlusion complicated by dentition defects. Kubanskij nauchnyj medicinskij vestnik. 2017;24(4);54-64. (In Russ., English abstract). DOI: 10.25207 / 1608-6228-2017-24-4-54-64.

29. ZELENSKY, V.A. Integral indicator for orthodontic carequality control / V.A. Zelensky, D.A. Domenyuk, M.V. Baturin, I.V. Zelensky, A.V. Kokareva, A.V. Zenina // Medical news of North Caucasus. 2014. Vol. 9. - No1. - P. 80-83. (In Russ., English abstract). DOI: 10.14300/mnnc.2014.09022. 30. Karslieva A.G., Domenyuk D.A., Zelensky V.A. Mixed saliva trace element composition in children with dentoalveolar anomalies through apparatus-involved treatment // Archiv EuroMedica, 2014. - Vol. 4. - No 1. - P. 29-35.

31. KorobkeEv, A.A. Changes in the structural elements of the temporomandibular joint with distal occlusion / A.A. Korobkeev, D.A. Domenyuk, E.G. Vedeshina, V.V. Konov, O.Yu. Lezhnina, Ya.A. Korobkeeva // Medical news of North Caucasus. 2017. - Vol. 12. - No 1. - P. 72-76. (In Russ., English abstract). DOI: 10.14300/mnnc.2017.12020.

32. KorobKeEv, A.A. The main forms of individual microdontia formed in the mixed dentition of permanent teeth / A.A. Korobkeev, D.A. Domenyuk, E.G. Vedeshina, S.B. Fischev, O.Yu. Lezhnina, Ya.A Korobkeeva // Medical news of North Caucasus. 2016. - Vol. 11. - № 3. - P. 474-476. (In Russ., English abstract). DOI: 10.14300/mnnc.2016.11110.

33. Kulikova, N.G. Evaluation of the effectiveness of pharmaco-physiotherapeutic treatment of catarrhal gingivitis on the results of the condition of mucosal immunity of oral cavity in women in the postpartum period / N.G. Kulikova D.A. Domenyuk, V.A. Zelen- 
sky, A.S. Tkachenko // Medical news of North Caucasus. 2017. - Vol. 12. - No 4. - P. 417-421. (In Russ., English abstract). DOI: 10.14300/mnnc.2017.12117.

34. Shkarin V.V., Domenyuk D.A., Porfiriadis M.P. DMitrienko D.S., DMitrienko S.V. Mathematical and graphics simulation for individual shape of maxillary dental arch // Archiv EuroMedica, 2017. - T.7. - No 1. - P. 60-65.

35. Vedeshina E.G., Domenyuk D.A., Dmitrienko S.V. Anatomic features of inclination and angulation of permanent teeth in case of different mesognathic dental arches. Kubanskij nauchnyj medicinskij vestnik. 2016;(1):16-23. (In Russ.) DOI:10.25207/1608-62282016-1-16-23.

36. Vedeshina E.G., Domenyuk D.A., Dmitrienko S.V. Correlation between shapes and sizes of dentofacial arches and their stable parameters. Kubanskij nauchnyj medicinskij vestnik. 2016;(3):33-38. (In Russ.) DOI:10.25207/1608-6228-2016-3-33-38.

37. Vedeshina E.G., Domenyuk D.A., Dmitrienko S.V. Determining torque and angulation of perma- nent teeth in cases of brachygnathic dental arches depending on dentition type. Kubanskij nauchnyj medicinskij vestnik. 2015;(6):23-30. (In Russ.) DOI:10.25207/1608-6228-2015-6-23-30.

38. Vedeshina E.G., Domenyuk D.A., DMitrienko S.V., Orfanova Z.S. Geometrical and graphic validation for patient management selection criteria in dental arches asymmetry. Kubanskij nauchnyj medicinskij vestnik. 2015;(2):23-28. (In Russ.) DOI:10.25207/1608-6228-2015-2-23-28.

39. Vedeshina E.G., Domenyuk D.A., DMitrienko S.V., DMitrienko D.S., Nalbandyan L.V., GAGLOYEVA N.F. Odontometric parameters in cases with mesognathic dental arches. Kubanskij nauchnyj medicinskij vestnik. 2015;(4):44-48. (In Russ.) DOI:10.25207/1608-6228-2015-4-44-48.

40. Shkarin V.V., Porfiriadis M.P., Domenyuk D.A., DMitrienko D.S., Dmitrienko S.V. Setting reference points for key teeth location in case of abnormal dental arch shape //Archiv EuroMedica. - 2017. - V.7. - No 2. - P. 111-117. 